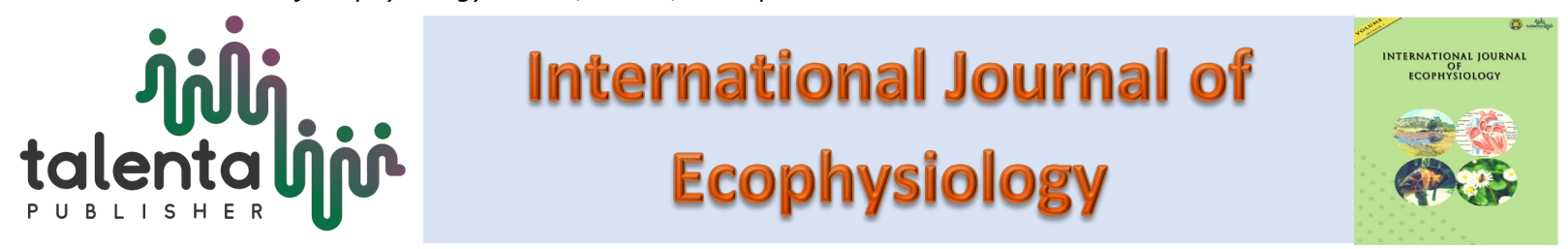

\title{
The Effect of Acetobacter xylinum Starter in Waste Liquid Pineapple Peel on the Properties of Nata de Pina
}

\author{
Dwi Juwita ${ }^{1}$, Kiki Nurtjahja ${ }^{* 2}$, Rahmiati ${ }^{1}$, Ferdinand Susilo ${ }^{1}$, Sartini ${ }^{1}$ \\ ${ }^{1}$ Biology, Study Program, Faculty of Science and Technology, Medan Area University, Jalan Kolam no.1, \\ Medan 20223, Indonesia \\ ${ }^{2}$ Department of Biology, Faculty of Mathematics and Natural Sciences, Universitas Sumatera Utara, \\ Jalan Bioteknologi no. 1 Medan, North Sumatera 20115, Indonesia
}

\begin{abstract}
Fresh pineapple waste consisted of saccharides, water, protein, lipid, vitamin and minerals that can be used by beneficiary microorganisms for production another food products. The aim of this study was to investigate physical properties nata de pina made from waste liquid pineapple peel using various starter concentrations and length of fermentation of Acetobacter xylinum. The starter used were 20,30 and $40 \% \mathrm{ml}$. Each 200 $\mathrm{mL}$ fresh waste containing the starter was incubated for 14,21 and 28 days at $29^{\circ} \mathrm{C}$. Nata properties such as yield, thickness, fibre and water content were determined. Results showed starter concentration and length of fermentation affect and significantly $(\mathrm{P}<0.05)$ different on nata thickness, yield and fiber content. The highest yield $(35,75 \%)$, thickness $(24.6 \mathrm{~mm})$ and fibre content $(4.43 \%)$ occurred at $40 \%$ starter after 28 days of fermentation. However, the optimum nata thickness occurred at 21 days. There is no significantly different $(\mathrm{P}<0.05)$ at nata moisture on starter concentration and length of fermentation. In conclusion, waste liquid pineapple peel is potential as a raw material source for making nata de pina with starter Acetobacter xylinum.
\end{abstract}

Keyword: Acetobacter xylinum, Fermentation, Nata de pina, Pineaple peel, Waste

Received 2 June, 2020 | Revised 20 July, 2020 | Accepted 20 August, 2020

\section{Introduction}

Pineapple (Ananas comosus) is one of tropical fruits that commonly consumed as fresh fruit or processed as preserved food such as canned fruit, jam, syrup, fruit juice and dehydrated products. The main objective of the processing products is to convert fresh pineapple as the perishable fruit into preserved products with longer life. Most pineapples are processed directly after harvest, however, in subsistence farming, the fresh fruits were processed for self consumption or sold to retailers in low price [1]. The waste of the fruit from home industries or

*Corresponding author at: Jl. Bioteknologi No. 1 Kampus Univ. Sumatera Utara, Padang Bulan, Medan, Indonesia 
large processing industries is produce in large amount of unusable waste material are generated [2]. The by product such as peel, residual pulp consisted of fibre, sugar and nutrients such as vitamins and minerals. Dacera et al., [3] reported the wastes from pineapple canneries have been used as the substrate for bromelian, organic acid, ethanol, etc. since these are potential source of sugars, vitamins and growth factors. Many studies have been carried out and use Acetobacter xylinum through fermentaion in making nata de pina. Nata can be made from any kinds of fruits including pineapple $[4,5]$, the processed product is stable and longer life.

Nata de pina is one of the fermentation culture product of A. xylinum in pineapple juice enriched with carbon and nitrogen under a controlled process. In the nata formation, these bacteria produce enzymes that can convert simple sugar into complex cellulose fibre [6]. The production of nata de pina can be used A. xylinum by inoculating the bacterial starter into pineapple juice [7]. The number of starter and chemical composition of medium used determine nata de pina properties. This studies have focus on the affect starter concentration of A. xylinum and length of fermentation on the yield, thickness, fibre and water content nata de pina produced from pineapple peel as a waste material obtained from fresh pineapple fruit.

\section{Materials and Methods}

\section{Starter Acetobacter xylinum}

Inoculum of A. xylinum used was obtained from culture collection of Microbiology Laboratory, Universitas Sumatera Utara. Starter was made by inoculating $20 \mathrm{~mL}$ of the bacterial suspension into $500 \mathrm{~mL}$ pineapple peel extract. The starter then was incubated for 7 days at $29^{\circ} \mathrm{C}$.

\section{Preparation pineapple peel and nata production}

A total of $8 \mathrm{~kg}$ pineapple peel were obtained from fresh pineapple fruit. The peel was rinsed in running water then sliced $(3-5 \mathrm{~cm})$, and homogenated using a waring blender. The homogenate was filtered and $2 \mathrm{~L}$ of the filtrate was added with $10 \mathrm{~g}$ urea, $200 \mathrm{~g}$ sucrose and acetic acid until $\mathrm{pH}$ 4. The broth were boiled $(100 \mathrm{oC})$, cooled until the temperature $29-30^{\circ} \mathrm{C}$. For nata production, the broth (each $200 \mathrm{~mL}$ in a sterile $250 \mathrm{ml}$ transparent glass jar) was inoculated to A. xylinum starter with concentrations 20,30 and $40 \%$. Each of the of the jar was thereafter incubated for 14,21 and 28 days at $29^{\circ} \mathrm{C}$. Each treatment was replicate 3 times.

\section{Determination of thickness and yield of nata}

Nata thickness was determined using calipers and the yield $(\mathrm{g} / \mathrm{v})$ was determined using gravimetric method with formula as follows: 


$$
\text { Yield }=\frac{\text { nata weight }(\mathrm{g}) \times 100 \%}{\text { volume }(\mathrm{g})}
$$

\section{Fibre content}

Nata fibre content was determined according to procedure Badan Stardardisasi Nasional [3] with formula as follows:

Fibre content $=\frac{(C-B)-(E-D) \times 100 \%}{A}$
$\mathrm{A}=$ weight sample $(\mathrm{g})$
$\mathrm{B}=$ weight filter paper $(\mathrm{g})$
$\mathrm{C}=$ weight filter paper + residue $(\mathrm{g})$
$\mathrm{D} \quad=\quad$ weight dish $(\mathrm{g})$
$\mathrm{E} \quad=\quad$ weight dish $+\operatorname{ash}(\mathrm{g})$

\section{Nata moisture}

Nata moisture was determined according to BSN [4], Five gram of nata in aluminum cup was dried using oven drying for 6 hours at $105 \mathrm{oC}$. The moisture was determined using formula:

$$
\text { Moisture }(\%)=\frac{(\mathrm{B}-\mathrm{C}) \times 100 \%}{\mathrm{~B}-\mathrm{A}}
$$

A $\quad=\quad$ weight of aluminum cup $(\mathrm{g})$

$\mathrm{B}=$ weight aluminum cup containing nata before dried $(\mathrm{g})$

$\mathrm{C}=$ weight aluminum cup containing nata after dried $(\mathrm{g})$

\section{Statistical Analysis}

We employed a completely randomized design factorial. The first and second factors were starter concentration and length of fermentation respectively. We analyzed the observed data using analysis of variance (ANOVA) for statistically significant differences.

\section{Result and Discussion}

\section{Nata thickness}

At the first 24 hour in all treatments showed air bubble at the surface of the medium. The fine fibre are distinct after fermentation $48 \mathrm{~h}$ particularly at 30 and $40 \%$ starter. The white thin layers are become thicker after fermentation $72 \mathrm{~h}$. The higher starter concentration and length of fermenation were followed the increasing thickness as shown in Figure 1. Starter concentrations have effect on nata thickness. Figure 1 shows starter concentration at 20, 30 and 40\% after 14 
days of fermentation have significantly different $(\mathrm{P}<0.05)$ on nata thickness. The thickness become increase and showed significanttly different after 21 day of fermentation. The highest thickness $(21.5 \mathrm{~mm})$ occurred at $40 \%$ starter concentration after 21 days and no significant different to thickness $24.6 \mathrm{~mm}$ for 28 days. Twenty one days was the optimum length of fermentation, we assumed no increasing thickness after 28 days of fermentation.

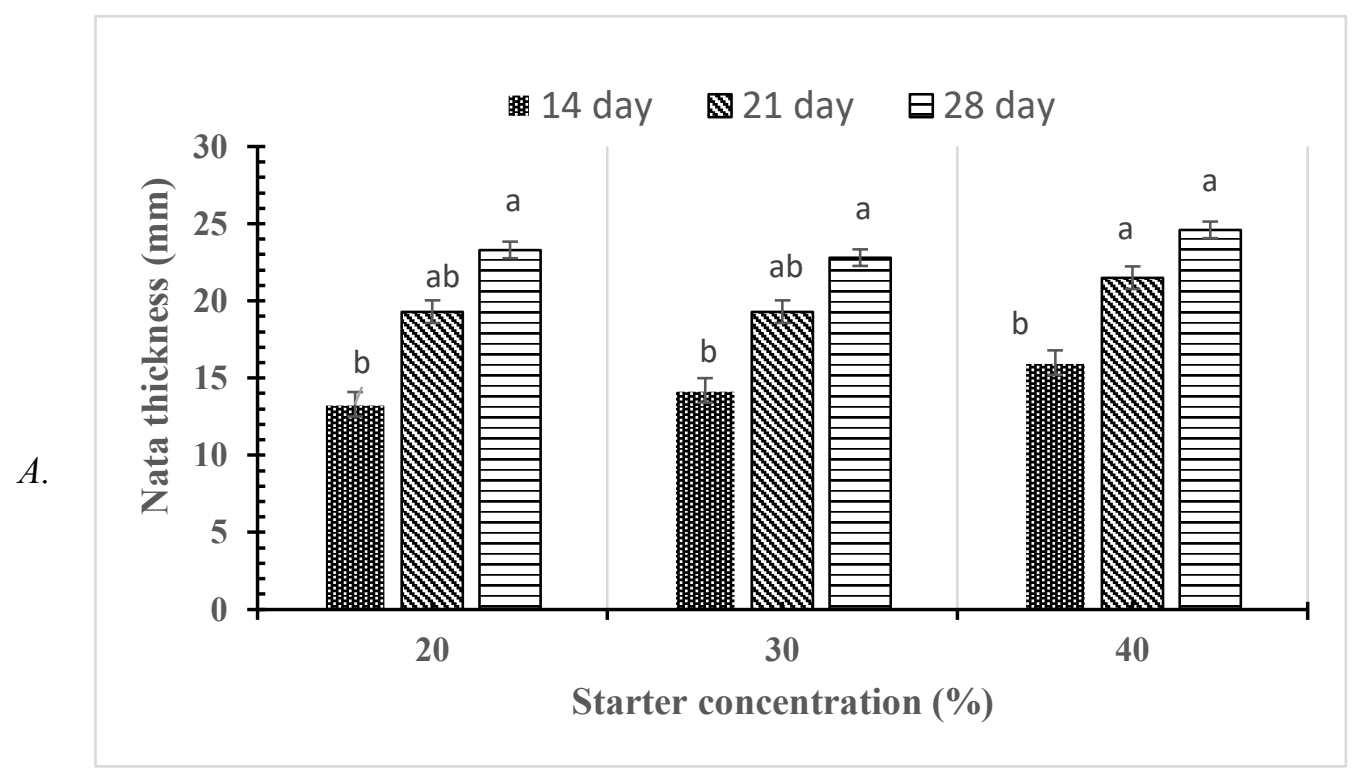

Figure 1. The effect of starter concentration (\%) and length of fermentation (day) on the thicknes $(\mathrm{mm})$ of nata de pina

\section{The yield of nata}

The yield of nata more affected by length of fermentation than that of starter concentration (Figure 2). Nata yield produced at each starter concentration $(20,30$ and $40 \%)$ used in this experiment have no significantly different on each length of fermentation $(14,21$ and 28 days).

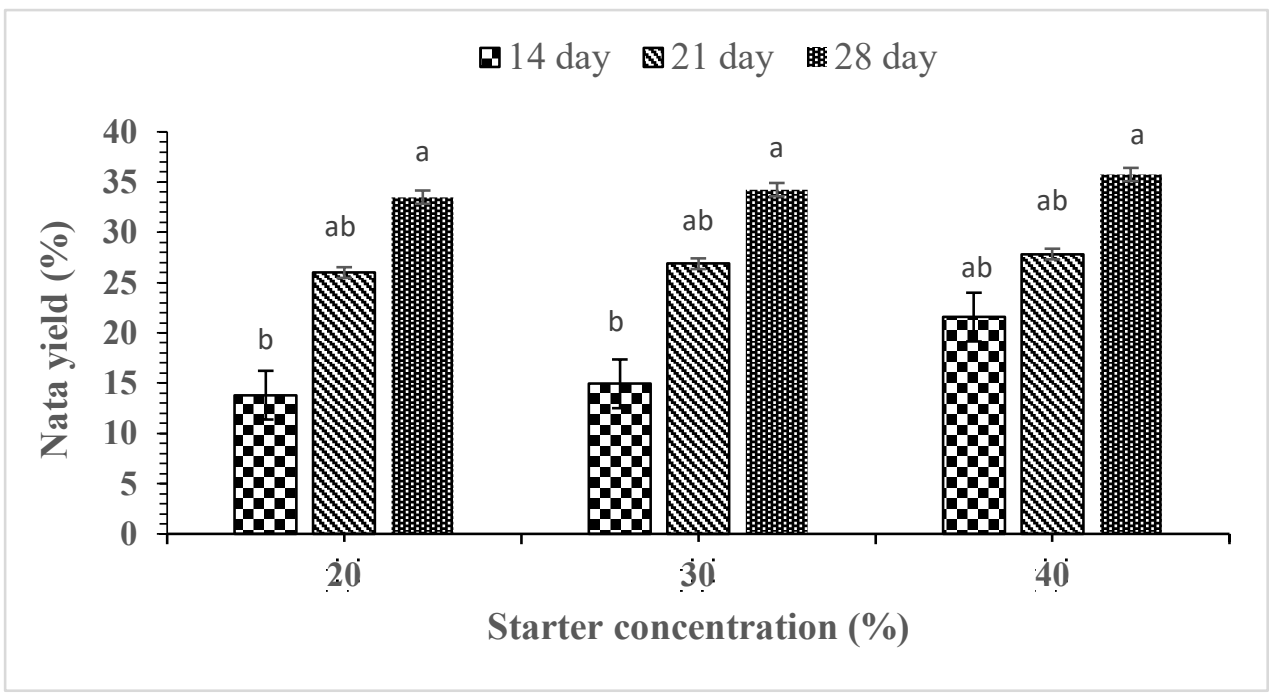

Figure 1. Degree of Lung damage $(\bar{X} \pm \mathrm{SD})$. Note: $\mathrm{T} 1=100 \mathrm{mg} / \mathrm{kgBW}, \mathrm{T} 2=141.42 \mathrm{mg} / \mathrm{kgBW}$, T3=200 mg/kgBW, T4= $28.82 \mathrm{mg} / \mathrm{kgBW}, \mathrm{T} 5=400 \mathrm{mg} / \mathrm{kgBW}$ 


\section{Fibre and moisture content}

Various levels of fibre content in various starter concentration and length of fermentation were obtained (Table 1).

Table 1. Fibre and moisture content nata de pina at different starter concentration Acetobacter xylinum and length of fermentation

\begin{tabular}{ccc}
\hline Treatments & Fibre content $(\%)$ & Moisture content $(\%)$ \\
\hline $\mathrm{K}_{1} \mathrm{~W}_{1}$ & 1.01 & 93.86 \\
$\mathrm{~K}_{1} \mathrm{~W}_{2}$ & 3.25 & 92.80 \\
$\mathrm{~K}_{1} \mathrm{~W}_{3}$ & 1.91 & 93.82 \\
$\mathrm{~K}_{2} \mathrm{~W}_{1}$ & 3.57 & 93.87 \\
$\mathrm{~K}_{2} \mathrm{~W}_{2}$ & 2.80 & 94.39 \\
$\mathrm{~K}_{2} \mathrm{~W}_{3}$ & 3.07 & 91.96 \\
$\mathrm{~K}_{3} \mathrm{~W}_{1}$ & 2.62 & 91.21 \\
$\mathrm{~K}_{3} \mathrm{~W}_{2}$ & 3.70 & 94.23 \\
$\mathrm{~K}_{3} \mathrm{~W}_{3}$ & 4.43 & 93.70
\end{tabular}

Note: $\mathrm{K}=$ starter concentration $1\left(\mathrm{~K}_{1} 20 \%, \mathrm{~K}_{2}=30 \%, \mathrm{~K}_{3}=40 \%\right)$. $\mathrm{W}=$ length of fermentation $\left(\mathrm{W}_{1}=14\right.$ day. $\mathrm{W}_{2}=21$ day, $\mathrm{W}_{3}=28$ day $)$

The lowest nata fibre $(1.01 \%)$ occurred at $20 \%$ starter for 14 days fermentation $\left(\mathrm{K}_{1} \mathrm{~W}_{1}\right)$ and the highest nata fibre $(4.43 \%)$ occurred at $40 \%$ for 28 days fermentation $\left(\mathrm{K}_{3} \mathrm{~W}_{3}\right)$. The presence of fibre indicate the ability of $A$. xylinum to convert simple sugar into complex cellulose produce fibre as repoted by Panesar et al. [10] and Suwanposri et al. [11]. The range nata moisture content in all treatments from $91.21\left(\mathrm{~K}_{3} \mathrm{~W}_{1}\right)$ to $94.39 \%\left(\mathrm{~K}_{2} \mathrm{~W}_{2}\right)$. Mosture content of nata has no affected on all treatments.

\section{Conclusion}

Acetobacter xylinum as a starter is potential for making nata from waste liquid pineapple peel. Nata thickness and yield produced the starter more influenced by length of fermentation than that of starter concentrations. Whereas, fibre content was affected by starter concentration and length of fermentation.

\section{REFERENCES}

[1] Your Highness, J., Argo, B.D., and Nugroho, W.A., influence the addition of sucrose and long fermentation on nata fiber content from pineapple juice (nata de pina). Journal of Tropical Agriculture Engineering and Biosystem. Vol.3. No.1. February 2015.

[2] Tanaka, K., Hilary, Z.D., and Ishizaki, A., Investigation of the utility of pineapple juice and pineapple waste material as low cost substrate for ethanol fermentation by Zymomonasmobilis. Journal of Bioscience and Bioengineering, 87: 642-646. 1999. 
[3] Dacera, D.D.M., Babel, S., and Parkpian, P., Potential for land application of contaminated sewage sludge treated with fermentated liquid from pineapple wastes. Journal of Hazardous Materials, 167: 866-872. 2009.

[4] Iguchi, M., Bacterial Cellulose A Masterpiece of Nature's Arts. Journal of Material Science, 261-270. 2000.

[5] Jaturapiree, E., Chaichana, E., Saowapark, T., Chuenpraphai, B., and Jaurapiree P, Production and chracterization of bacterial cellulose produced by Acetobacter xylinum TIS TR 975 from pineapple peel juice. RMUTP Research Journal Sci. and Tech. 13(1): 1-13. 2019.

[6] Nugroho, D.A. and Aji, P., Characterization of nata de coco produced by fermentation of immobilized Acetobacter xylinum. Agriculture and Agricultural Science Procedia, 3: 278282. 2015.

[7] Lestari, P., Elfrida, N., Suryani, A., and Suryadi, Y., Study on the production of bacterial cellulose from Acetobacter xylinum using agro-waste. Jordan Journal of Biological Sciences, 7(1): 75-80, 2014.

[8] National Standardization Agency, How to test food and beverages. SNI 01-2891-1992. Jakarta, BSN, p.36. 1992.

[9] National Standardization Agency, Chemical Testing Method part 2: Determination of water content in fishery products, SNI 01-2354-2006, Jakarta, BSN, p.7. 2006.

[10] Panesar, P.S., Chavan, Y., and Chopra, H.K., Production of Microbial Cellulose: Response Surface methodology Approach. Carbohydrate Polymers 87(1): 939-934. 2012.

[11] Suwanposri, A., P. Yukphan, and Y. Yamada, Identification and Biocellulose Production of Gluconacetobacter Strains Isolated from Tropical Fruits in Thailand. Maejo International J.Sci. and Technol. 7(01): 70-82. 2013. 